\title{
Human leucocyte antigens in Crohn's disease and ulcerative colitis
}

\author{
M. H. GLEESON ${ }^{1}$, J. S. WALKER, J. WENTZEL, J. A. CHAPMAN, AND \\ R. HARRIS
}

From the Department of Medical Genetics and Gastroenterology, Manchester Royal Infirmary

SUMMARY The frequency of occurrence of 15 of the commoner human leucocyte antigens was determined in 18 patients with Crohn's disease and in 16 patients with ulcerative colitis, using an in-vitro lymphocyte cytotoxicity test (Harris, Wentzel, Cocking, Dodsworth, and Ukaejiofo, 1970). The overall results showed that, with the exception of human leucocyte antigen 3 in patients with Crohn's disease, in neither disease was there any major difference in any of the other antigen frequencies compared with a panel of 50 healthy controls. Nor was there an excess frequency of any particular antigen occurring in both Crohn's disease and colitis.

There have been a number of reports of the familial occurrence of both Crohn's disease and ulcerative colitis (Houghton and Naish, 1958; Morris, 1965). Although the relationship between the two diseases is not clearly understood, it is recognized that relatives of patients with Crohn's disease may also suffer from ulcerative colitis (Sherlock, Bell, Steinberg, and Almy, 1963) and vice versa (Kirsner and Spencer, 1963). McConnell (1971) postulated that the two polygenic systems which determine liability to the two diseases may have a number of genes in common. Blood group frequencies in the two diseases have already been studied. Winstone, Henderson, and Brooke (1960) found that in ulcerative colitis there was no correlation with ABO blood groups, D rhesus type, or secretor status. Boyd, Heisler, and Orowan (1961) confirmed these results but did find a correlation with the homozygous CC rhesus type although there was heterogeneity in their test material. We have found no correlation with ABO blood group or D rhesus type in Crohn's disease (Chapman and Gleeson, 1972). The reported association between erythrocyte glucose-6-phosphate dehydrogenase (G6PD) deficiency and Crohn's disease (Sheehan, Necheles, Lindeman, Meyer, and Patterson, 1967) could not be confirmed (Katsaros and Truelove, 1969).

To date there has been no investigation of the type of human leucocyte antigens ('tissue type' or 'transplantation antigens') in patients with Crohn's

Received for publication 21 March 1972.

${ }^{1}$ Requests for reprints to M. H. Gleeson, Crumpsall Hospital, Manchester 8 . disease or ulcerative colitis, or for that matter in any other gastrointestinal disorders. It seemed to us important to initiate this line of investigation as it is now being claimed that certain specificities of human leucocyte antigens show an increased frequency in other diseases such as childhood leukaemia (Walford, Finkelstein, Neerhout, Konrad, and Shanbrom, 1970), Hodgkin's disease (Amiel, 1967; Forbes and Morris, 1970); Zervas, Delamore, and Israels, 1970), and in autoimmune diseases such as systemic lupus erythematosus (unpublished observations by Waters, Konrad, and Walford, 1970).

\section{Methods}

The human leucocyte antigen specificities $(1,2,3$, $\left.5,7,8,9,10,11,12,13, \mathrm{BB}, \mathrm{LND}, \mathrm{R}^{*}, \mathrm{AA}\right)$ were investigated using accredited human leucocyte antigen antisera in a microcytotoxicity test on lymphocytes. (Any individual can possess a maximum of four different human leucocyte antigens.)

LYMPHOCYTE SEPARATION AND MICROCYTOTOXICITY TEST (HARRIS et al, 1970) Lymphocytes were obtained from fresh heparinized venous blood using a Ficoll-Triosil density gradient with centrifugation.

After serial saline washes and the addition of fresh rabbit serum as a source of complement, the antigen specificities of the lymphocytes were determined by assaying their susceptibility to cytotoxicity by various human leucocyte antigen antisera. Several different antisera for most specificities were used. The antisera were prespotted below mineral oil on glass 
plates and $1 \mathrm{ml}$ of the complement cell suspension was added to each microdroplet of antiserum. After incubation at $37^{\circ} \mathrm{C}$ and the addition of $1 \%$ trypan blue, cytotoxicity was assessed by estimating the proportion of blue-stained cells visualized through an inverted phase-contrast microscope. All antisera and an $\mathrm{AB}$ serum control were investigated in duplicate. Greater than $\mathbf{4 0} \%$ cytotoxicity in duplicates was taken to indicate the presence of a particular human leucocyte antigen specificity, provided $A$ that concordance between different antisera was $B$ obtained.

\section{Case Material}

The type of human leucocyte antigens from a total of 34 patients was investigated. There were 18 patients with Crohn's disease. Of these the diagnosis had been confirmed by histology in seventeen. Of the 18 patients, 17 had colonic involvement and 15 had ileal disease. Their ages ranged from 22 to 68 years. There were 16 patients with ulcerative colitis. In all the diagnosis had been made by barium enema and sigmoidoscopy. In nine patients, histological confirmation of the diagnosis was available. Their ages ranged from 16 to 66 years. The panel of 50 controls was composed of healthy laboratory and medical personnel, with an age range of 17 to 45 years. Their tissue types were determined using the same human leucocyte antigen antisera as were used to study the groups with Crohn's disease and ulcerative colitis.

\section{Results}

The distribution of the human leucocyte antigens in Crohn's disease and ulcerative colitis as compared with the control panel is shown in the accompanying Table. It can be seen that there is no antigen which occurs with excess frequency, compared with normal controls, in both Crohn's and ulcerative colitis. There is an excess of human leucocyte antigen 3 in the Crohn's group ( $44 \%$ ), and this difference is statistically significant when compared with the control frequency of $20 \%\left(\chi^{2}=5.78 ; \mathrm{P}<0.05\right)$. However, the human leucocyte antigen 3 antisera used are not monospecific, and crossreact with human leucocyte antigen.

Thus, although unlikely, the lower frequency of the latter antigen in the Crohn's group or the higher frequency of human leucocyte antigen 3 may simply represent inevitable variations in the interpretation of the cytotoxicity results. The absence of the $R^{*}$ specificity in patients with Crohn's disease and the human leucocyte antigen 5 specificity in those with ulcerative colitis might be regarded as surprising, but these results are not statistically significant.

\begin{tabular}{lccc}
\hline $\begin{array}{l}\text { Human Leucocyte } \\
\text { Antigen Specificity }\end{array}$ & $\begin{array}{l}\text { Control Group } \\
\text { (50 subjects) }\end{array}$ & $\begin{array}{l}\text { Crohn's Disease } \\
\text { (18 patients) }\end{array}$ & $\begin{array}{l}\text { Ulcerative } \\
\text { Colitis } \\
\text { (16 patients) }\end{array}$ \\
\hline 1 & 32 & 27 & 43 \\
$A$ & 44 & 44 & 62 \\
3 & 20 & 44 & 20 \\
5 & 8 & 17 & 0 \\
7 & 36 & 50 & 43 \\
8 & 24 & 33 & 31 \\
9 & 24 & 27 & 13 \\
10 & 6 & 6 & 13 \\
11 & 16 & 6 & 6 \\
12 & 32 & 17 & 31 \\
13 & 4 & 6 & 0 \\
BB & 20 & 11 & 13 \\
LND & 12 & 22 & 20 \\
R* & 12 & 0 & 13 \\
AA & 6 & 6 & 0 \\
\hline
\end{tabular}

Table Percentage frequency of 15 human leucocyte antigens in patients with Crohn's disease, ulcerative colitis, and in control subjects

\section{Discussion}

Interest in the possibility that histocompatibility genes may have a functional relationship to disease states is increasing. The observation that certain alleles of the H-2 system (the mouse homologue of the human leucocyte antigen system of man) are strongly associated with predisposition to the development of various types of murine leukaemia (Lilly, Boyse, and Old, 1964) has provoked study of the frequency of leucocyte antigens in human lymphoreticular disorders. It would appear that the frequency of human leucocyte antigen 5 specificity, and related antigens, may be higher in patients with Hodgkin's disease (Amiel, 1967; Forbes and Morris, 1970; Zervas et al, 1970). Walford et al (1970) have produced evidence that childhood leukaemia shows a strong correlation with the (2, Merritt) gene of the human leucccyte antigen system.

It seems to us reasonable to anticipate that, because transplantation antigens are inherited characteristics of lymphocytes, they may be concerned in the pathogenesis of diseases in which there is evidence both of a genetic predisposition to their development and also of abnormalities of lymphocyte function. Evidence for a genetic predisposition to Crohn's disease and ulcerative colitis has already been discussed. In both diseases there is abnormal cytotoxicity of patients' lymphocytes for colonic epithelial cells (Perlmann and Broberger, 1960; Shorter, Cardoza, Spencer, and Huizenga, 1969). Furthermore, in both Crohn's disease and ulcerative colitis there have been reports of abnormalities of lymphocyte transformation (Walker and Greaves, 1969; Brown, Taub, Present, and Janowitz, 1970; Stefani and Fink, 1967). Thus, on the basis of our 
hypothesis, a study of leucocyte antigens in inflammatory bowel disease was indicated. Although this series is small and it is therefore unjustified to attempt definitive conclusions, it would seem to us unlikely that there is any strong association between the human leucocyte antigen groups and inflammatory bowel disease. However, it would be interesting if a second independent series demonstrated a similar pattern of departures from the normal frequencies, particularly the excess frequency of human leucocyte antigen 3 in patients with Crohn's disease.

We acknowledge the expert technical assistance of Mrs I. Wentzel, and are also grateful to Dr H. T. Howat, Dr R. B. Holmes, and Mr H. B. Torrance for permission to study their patients, and Miss G. I. Smith for assistance in the preparation of this manuscript.

\section{References}

Amiel, J. L. (1967). Study of the leukocyte phenotypes in Hodgkin's disease. In Histocompatibility Testing, pp. 79-81. Munksgaard, Copenhagen.

Boyd, W. C., Heisler, M., and Orowan, E. (1961). Correlation between ulcerative colitis and Rh blood groups. Nature (Lond.), 190, 1123-1124.

Brown, S. M., Taub, R. N., Present, D. H., and Janowitz, H. D. (1970). Short term lymphocyte cultures in regional enteritis. Lancet, 1, 1112

Chapman, J. A., and Gleeson, M. H. (1972). Unpublished data.

Forbes, J. F., and Morris, P. J. (1970). Leucocyte antigens in Hodgkins disease. Lancet, $2,849-851$.

Harris, R., Wentzel, J., Cocking, H., Dodsworth, H., and Ukaejiofo E. O. (1970). Errors in allograft donor typing. A modified microcytotoxic test. In Histocompatibility Testing, edited by $\mathbf{P}$. I. Terasaki, pp. 603-616. Munksgaard, Copenhagen.
Houghton, E. 'A. W., and Naish, J. M. (1958). Familial ulcerative colitis and ileitis. Gastroenterologia (Basel), 89, 65-74.

Katsaros, D., and Truelove, S. (1969). Regional enteritis and glucose6-phosphate dehydrogenase deficiency. New Engl. J. Med., 281, 295-296.

Kirsner, J. B., and Spencer, J. A. (1963). Family occurrences of ulcerative colitis, regional enteritis and ileocolitis. Ann. intern. Med., 59, 133-144.

Lilly, F., Boyse, E. A., and Old, L. J. (1964). Genetic basis of susceptibility to viral leukaemogenesis. Lancet, 2, 1207-1209.

McConnell, R. B. (1971). Genetics and gastroenterology. Gut, 12, 592-598.

Morris, P. J. (1965). Familial ulcerative colitis. Gut, 6, 176-178.

Perlmann, P., and Broberger, O. (1960). Auto-antibodies against antigen derived from colon in the microsomes of regional colonic lymph glands in human ulcerative colitis. Nature (Lond.), 188, 749-751.

Sheehan, R. G., Necheles, T. F., Lindeman, R. J., Meyer, H. J., and Patterson, J. F. (1967). Regional enteritis and granulomatous colitis associated with erythrocyte glucose-6-phosphate dehydrogenase deficiency New Engl. J. Med., 277, 1124-1126.

Sherlock, P., Bell, B. M., Steinberg, H., and Almy, T. P. (1963). Familial occurrence of regional enteritis and ulcerative colitis. Gastroenterology, 45, 413-420.

Shorter, R. G., Cardoza, M., Spencer, R. J., and Huizenga, K. A. (1969). Further studies of in vitro cytotoxicity of lymphocytes from patients with ulcerative and granulomatous colitis, for allogeneic colonic epithelial cells, including the effects of colectomy. Gastroenterology, 56, 304-309.

Stefani, S., and Fink, S. (1967). The ulcerative colitis lymphocyte: reaction to E. coli 014 and colon antigens. Scand. J. Gastroent., 2, 333-336.

Walford, R. L., Finkelstein, S., Neerhout, R., Konrad, P., and Shanbrom, E. (1970). Acute childhood leukaemia in relation to the HL-A human transplantation genes. Nature (Lond.), $225,461-462$

Walker, J. G., and Greaves, M. F. (1969). Delayed hypersensitivity and lymphocyte transformation in Crohn's disease and proctocolitis. (Abstr.) Gut, 10, 414.

Waters, H., Konrad, P., and Walford, R. L. (1970). Unpublished observations, quoted by Walford, R. L., Finkelstein, S., Neerhout, R., Konrad, P., and Shanbrom, E. (1970). Nature (Lond.), 225, 461-462.

Winstone, N. E., Henderson, A. J., and Brooke, B. N. (1960). Blood groups and secretor status in ulcerative colitis. Lancet, 2, 64-65.

Zervas, J. D., Delamore, I. W., and Israels, M. C. G. (1970). Leucocyte phenotypes in Hodgkin's disease. Lancet, 2, 634-635. 